\title{
LITERATION MOVEMENT FROM TANAH OMBAK'S COMMUNITY
}

\author{
EkaVidya Putra \\ Department of Sociology, State University of Padang \\ Ekavidyaputra@gmail.com
}

\begin{abstract}
Nowadays, Character education becomes the attention of many parties. The key to character education is the availability of a positive character environment. Because character building is not enough just to provide knowledge about which is good attitude and what is bad as taught in school. This misunderstanding of school is the cause of character education and failure. Intended for character building requires a character environment that provides good examples to its members. The problem is that there are many character environments that do not support the building of good characters. Bad character environments can be seen in slum area. Slums, identical to poverty, low levels of education, many criminal acts, promiscuity and other negative behaviors. By using a new institutional approach . Data collection is done by qualitative method, through observation, interview and literature study. The success of the Tanah Ombak Community manipulates the institutional environment can not be separated from two things. First, there are actor who become key figures. Second, there in collectively shared values that drives ideas. How the environment is manipulated can be seen from the three aspects, regulative, normative and cognitive. Regulatively, many emergence of positive rules for character development. Normatively, bad old habits are replaced by positive new habits for character building. Finally, cognitively new knowledge emerges for the new characters building.
\end{abstract}

Keywords: character environment, manipulation, Komunitas Tanah Ombak

\section{INTRODUCTION}

Characters associated with mental qualities and unique behavior of one's person. Character is not genetic, but the role model results of the surrounding environment. A good environment could form a positive character, otherwise a bad environment forms a negative character. To be one whose has a good character, it needs a conducive environment, healthy and positive. The environment affects individuals through the interaction's process. The five senses become an important component when one interacts and socializes with the environment. Experience interact with this environment which then affects a person's character.

New Institutional approach besides distinguished on the environment's side. but also on individual and groups as an actor. Actors in the new institutional approach, more free and independent. Besides it, Individuals or groups also have the ability to manipulate the environment. It means that, the environment could affect the behavior, but the actor also has the ability to respond to pressures coming from the environment and at the same time having the 
ability to influence the environment. The most important thing here is how the environment is produced and reproduced by actors both as individual or collective. How individuals put themselves in social relations, interpret and respond to their institutional context (Walter W. Powell and Patricia Bromley; 2013). The environment is not seen as a fixed and stable reality, but as the construction of individual minds and their actions. Who will manipulate the environment? In order to manipulate the environment, we need creative individuals who have social positions and skills enable them to recognize problems or opportunities and make use of enabling conditions to change the social order (Battilana, Leca and Boxenbaum, 2009). Except to creative's individuals, manipulation can also be done by the authorities (Douglass C. North; 2013).

Lauree Beth Stedje (2010) notes the success of character education never woks itself. School is one of the environment that educuating as long as students are in school environment. In the school environment, teachers are models. But, outside there is a playing environment and family environment. In the family environment, there are family members, especially father and mother who being a model. While the model's playing environment is the community. The playing environment and the larger family environment influence the formation of a person's character, because the interaction takes place longer. During this time many research and attentions was focused on the formation of character in school and family environment. Whereas how the playing environment forms one's characters is rarely as a concern.

However, Not all playing environments are conducive to form the positive characters. In some places, the playing environment provides a negative experience for the formation of one's character. For example in slums. This paper will make a study of how actors - both in individual and collective terms - manipulate the playing environment in slums both in physical and nonphysical terms into positive character environments for community, especially children. This paper will take a case in the slums on the coast of Padang.

\section{METHODOLOGY}

The study was conducted with qualitative approach. Data collection was done through participant observation, interviewing with a number of key actors and collecting documentation data. The study will be conducted on Tanah Ombak's community. 


\section{RESEARCH FINDINGS}

\section{A. PROFILE OF PASIA CHILDREN" IN THE VICIOUS GANG}

Pasia children literally can be interpreted as a child who lives in the coast. But the term of Pasia children" in the local sense is sometimes interpreted not in the same way as literal. Pasia Children" has a negative meaning, because there is a stigma in which is attached to a Pasia Children. Stigma of Pasia Children is close to misbehavior, slums, naughty, and rough talking. While Gang Satan, showing the location, a gang is located at Jalan Purus III, District Padang Barat of Padang, West Sumatera Province. Gang Satan is not the real name of the alley. Gang Satan is a name attached by outsiders to the alley.

Gang Satan is a slum with bad condition and unhealthy living standards. From the economic standards, Gang Satan is a poor area of the city. While from social, cultural and educational, Gang Satan is not feasible for the growth of positive character. When we go to Gang of Satan, we will be familiar hearing harsh words and rough talking (bacaruik). Drinking liquor, narcotics, gambling, motorcycle thieves, are familiar scenery in Gang Satan. The above conditions correlate with low levels of their community education, in which most of them only graduating from high school. The similar condition are also found in the family environment, as scolded, harsh speech, intimidating such a model in educatind the children. Profile of Pasia children in Gang Satan, can not be separated from character environment. The character environment provides negative information and then was replicated. Children through their senses, recording and capturing the messages given by their environment.

\section{B. TANAH OMBAK'S COMMUNITY (Pasia Children)}

Tanah Ombak's Community is an organization which present at Satan Gang and make efforts to manipulate the environment. The institutional community of Tanah Ombak can be described as follows:

First, the Core (Core Value) Although not mentioned in a sentence, but what is revealed in the above can be equivalent with the value of the core (core value) and objectives core (core purpose) of the organization. The core value is the essential lesson and make the organization dynamic. The core value attached to the organization, in this case core inherent in the Tanah Ombak's Community 1 . In this case, the core values are in the two key actors of Tanah Ombak's Founder: Syuhendri Dt. Siri Marajo $\underline{2}$ and Yusrizal KW $\underline{3}$. Both actors have experience in assisting communities. Both have also worked by founding many communities before. 
Second, Organizational Structure of Tanah Ombak is simple and sleek. Formally, organizational structure of Tanah Ombak can be classified simply, consists of two groups, namely founder and board. So there is not much bureaucracy in decision making. The lean organizational structure aims to be more effective for the movement of the Tanah ombak. In this case, the community of Tanah Ombak prefers the functional to the structural position. The main goal of Tanah Ombak's community is the achievement goal in community development.

Third, participatory local community. The management personnel of Tanah Ombak is the Gang Satan community and the community volunteers. Local community participation becomes the solution to the closed structure of Gang Satan society. Participation becomes important for inclusive character education.

Fourth, accountability and transparency of financial management. Financial management is vulnerable parts in organizational management. The source of funding of Tanah Ombak mostly comes from donors. Donors and the amount of money funded is not fixed. Other sources of finance come from the program. Unfortunately, the community does not have a financial SOP yet. Monitoring the use of funds, monitoring the use of funds rests on the principle of transparency and accountability among community members and communities. Because personnel, the relationship between staff is very close and emotionally bound. In addition, the lean organizational structure also facilitates the control function in finance.

Fifth, Branding Strategy. The interesting strategy of Tanah Ombak is in publication. They do not use the conventional media, but through strategy of branding that is social media. Through the power of branding strategy, At the end of 2016, Tanah Ombak to be the frst regional champion in the Gramedia Reading Community of Sumatra Competition. This accomplishment was followed by many book as prizes from Gramedia. In the same year the Tanah Ombak attract Indonesian Reading Ambassador, Najwa Shihab, to officially release Tanah Ombak"s Vespaㄴ. In early 2017, KW and Syuhendri were invited to the palace by President Jokowi to receive the award as a literacy activist.

\section{MANIPULATING THE PLAYING ENVIRONMENT}

As what is in the new institutional approach, actors in terms of individual or collective has the ability to manipulate the environment. The kind of manipulation which is done as follows:

First, Setting up the reading garden. Proverb states "The book is like an ice breaking ax that could melt the frozen sea that stretches in our souls". The important thing here is how to attract 
children to read. The strategy is making reading a book as a password to participate in other activities. Like eating together, painting, story telling, singing and more. Until finally reading becomes a habit of children.

Second, inviting a lot of good people to Tanah Ombak. One of the problems in the early years of Tanah Ombak was the exclusive society. Inviting many good people will be a direct example for society. Simultaneously it shows that many people are good and also care about their environment. At last, they encourages desire to imitate and improve themselves and also the environment.

Third, keep creativity, innovative and participatory society. There are three basic concepts that become the key word in implementing the program in Tanah Ombak, that is creativity, innovative and participative. Creativity is the ability to think, develop something new and different in solving problems and finding opportunities.

Fourth, open public space for children. Children are introduced into the public sphere so that could foster their self-confidence. As a first step, they perform in Tanah Ombak and witnessed by Tanah Ombak's community, then watched by outsiders and finally they have a stages outside Tanah Ombak. Even The children of Tanah Ombak are now participating in a number of performances by outside organizers.

Fifth, Tumpang Sari Activities. All activities of Tanah Ombak's children titled literation, but in the implementation of activities always directed by efforts to influence the character environment. For example, in instilling courtesy values-children are taught to speak politely not to get dirty words-to get used to greeting every visitor who visit Tanah Ombak, to say thank every one of them to get something. Another example is to instill responsible values. In this case the children always do thoroughly the work given, work without having to wait for orders, and so forth. Thus, character formation does not necessarily have to provide character education in a theoretical sense but rather to the involvement of children in the process. So that process provides a direct experience that characterizes the child.

\section{CONCLUSION}

Overall the five ways above are effective for manipulating the environment, both the playing environment and the family environment. Effectiveness can be seen from the shift that occurs in 
the regulation, values and norms and also cognitive of the community. In this case the existence of creative actors became the key to the success of the Tanah Ombak's Community in manipulating the environment. Creative actors succeed in creating shared values and open up more inclusive public spaces

\section{LIST OF LIBRARY}

Victor Nee (2003), New Institutional, Economic and Sociological. Princeton: Princeton University Press.

Victor Nee (2003), Sources of the New Institutionalis. Https://www.russellsage.org

Walter W. Powell \& Patricia Bromley (2013) New institutionalism in the Analysis of Complex Organizations. Http://www.patriciabromley.com/PowellBromleyEncyclopedia.pdf

Douglass C.North (2013). Institutional Change: A Framework of Analysis. Https://www.iei.liu.se/nek/730A22/filarkiv-2013/della.pdf

Lauree Beth Stedje, (2010). Nuts and Bolts of Character Education. Character First 13800 N. Benson Road, Suite 206 Edmond, Oklahoma 73013.

Jacques S. Benninga (2003). The Relationship of Character Education Implementation and Academic Achievenent in Elementary Schools. Journal of Research in Character Education Vol. 1, No. 1, 2003

William G. Thompson, (2002). The Effects of Character Education on Student Behavio. Electronic Theses and Dissertations. East Tennessee State University.

1 Name of the Land of Waves taken from the realities of life of people who live dipingir beach. Tanah Ombak can be understood as the strength of the coastal community in stifling the hard life. Same as the shore survives the strong waves.

2 Syuherdri Dt. Siri Marajo is a civil servant working in Taman Budaya Kota Padang. Graduated from S2 at the Department of Theater at ISI Yogyakarta.

3 Yusrizal KW is a poet and an activist for literacy drive in West Sumatra.

4 Vesva Land Reader Wave is looking for a library moves the reader by driving a Vespa. 